\title{
The mitochondrial paradigm for cardiovascular disease susceptibility and cellular function: a complementary concept to Mendelian genetics
}

\author{
David M Krzywanski, ${ }^{*, 1}$ Douglas R Moellering, ${ }^{*, 2}$ Jessica L Fetterman ${ }^{1}$, Kimberly J Dunham-Snary ${ }^{1}$, \\ Melissa J Sammy ${ }^{1}$ and Scott W Ballinger ${ }^{1}$
}

While there is general agreement that cardiovascular disease (CVD) development is influenced by a combination of genetic, environmental, and behavioral contributors, the actual mechanistic basis of how these factors initiate or promote CVD development in some individuals while others with identical risk profiles do not, is not clearly understood. This review considers the potential role for mitochondrial genetics and function in determining CVD susceptibility from the standpoint that the original features that molded cellular function were based upon mitochondrial-nuclear relationships established millions of years ago and were likely refined during prehistoric environmental selection events that today, are largely absent. Consequently, contemporary risk factors that influence our susceptibility to a variety of age-related diseases, including CVD were probably not part of the dynamics that defined the processes of mitochondrial-nuclear interaction, and thus, cell function. In this regard, the selective conditions that contributed to cellular functionality and evolution should be given more consideration when interpreting and designing experimental data and strategies. Finally, future studies that probe beyond epidemiologic associations are required. These studies will serve as the initial steps for addressing the provocative concept that contemporary human disease susceptibility is the result of selection events for mitochondrial function that increased chances for prehistoric human survival and reproductive success.

Laboratory Investigation (2011) 91, 1122-1135; doi:10.1038/labinvest.2011.95; published online 6 June 2011

KEYWORDS: cardiovascular disease; evolution; genetics; mitochondria; oxidative stress

With the exception of the worldwide Spanish influenza epidemic of 1918, cardiovascular disease (CVD) has been the leading cause of mortality and morbidity in the United States every year since $1900 .{ }^{1}$ Consequently, many studies have investigated the potential causes of CVD, and it is generally accepted that oxidative stress mediated changes within the cardiovascular milieu are among the most popular postulated mechanisms of CVD development. ${ }^{2-7}$ Oxidative stress is caused by a collective grouping of reactive oxygen and nitrogen species (ROS and RNS, respectively) that are capable of disrupting cell function and exerting cytotoxic effects when generated in amounts beyond the antioxidant capacity of the cell. The concept that oxidative stress is important in the pathogenesis of CVD was conceived from studies that noted the cytotoxic and atherogenic properties of oxidized
LDL (oxLDL) cholesterol. ${ }^{8-12}$ Subsequently, it became apparent that vascular dysfunction can be linked to increased oxidant stress; oxidant stress can have several biological effects, including the peroxidation of polyunsaturated fatty acids in membrane or plasma lipoproteins, direct inhibition of mitochondrial respiratory chain enzymes, inactivation of membrane sodium channels, and DNA damage. ${ }^{2,3,5-7,13-22}$ These findings are consistent with the notion that CVD risk factors increase oxidative stress and contribute to a proinflammatory environment. ${ }^{5,11,12,23-35}$ Whereas the majority of these studies regard atherosclerotic disease, oxidative stress also has been implicated as an important factor in many other forms of cardiovascular-related maladies, including hypertension and cardiometabolic disease/syndrome. ${ }^{36-39}$ Although atherosclerosis and hypertension are often

\footnotetext{
'Division of Molecular and Cellular Pathology, Department of Pathology, The University of Alabama at Birmingham, Birmingham, AL, USA and ${ }^{2}$ Department of Nutrition Sciences, The University of Alabama at Birmingham, Birmingham, AL, USA

Correspondence: Dr SW Ballinger, PhD, Division of Molecular and Cellular Pathology, Department of Pathology, G019F Volker Hall, 1530 3rd Avenue South, Birmingham, AL 35294-0019, USA.

E-mail: sballing@uab.edu

*These authors contributed equally to this work.
} 
pathologies ultimately associated with cardiometabolic syndrome, individuals with hypertension or atherosclerosis do not always have cardiometabolic disease. The classic traits of visceral obesity and insulin resistance are associated with cardiometabolic syndrome, although other traits typically linked with metabolic syndrome are common as well. Multiple early definitions of metabolic syndrome have been related from different organizations including: the International Diabetes Federation (IDF), ${ }^{40}$ the revised National Cholesterol Education Program (NCEP; ATP III criteria), ${ }^{41}$ the World Health Organization (WHO) ${ }^{42}$ and the European Group for the Study of Insulin Resistance (EGIR). ${ }^{43}$ Based on a joint interim statement in 2009 from the American Heart Association (AHA), National Heart Lung Blood Institute (NHLBI), World Health Federation, International Atherosclerosis Society, International Association for the Study of Obesity, and IDF consensus statement, ${ }^{44}$ the criteria for clinical diagnosis of the metabolic syndrome include having three of five of the following (or drug treatment for them): some form of insulin resistance (impaired glucose tolerance or impaired fasting glucose $(\geq 100 \mathrm{mg} / \mathrm{dl}))$, hypertension (systolic $\geq 130$ and/or diastolic $\geq 85 \mathrm{~mm} \mathrm{Hg}$ ), dyslipidemia (higher triglycerides $(\geq 150 \mathrm{mg} / \mathrm{dl}, 1.7 \mathrm{mmol} / \mathrm{l})$, and lower HDL (males $<40 \mathrm{mg} / \mathrm{dl}$, $1.0 \mathrm{mmol} / \mathrm{l}$; females $<50 \mathrm{mg} / \mathrm{dl}$, $1.3 \mathrm{mmol} / \mathrm{l})$ ), and country-specific elevated waist circumference and abdominal obesity (USA, AHA/NHLBI ATP III thresholds: males $\geq 94-102 \mathrm{~cm}$; females $\geq 80-88 \mathrm{~cm}$ ) and all of these risk factors have been linked to oxidative stress. ${ }^{45-48}$ Among the potential cellular origins of oxidative stress, studies have shown multiple sources to be important, including $\mathrm{NAD}(\mathrm{P}) \mathrm{H}$ oxidase, xanthine oxidase, and myeloperoxidase. ${ }^{13,49-60}$ More recently, the mitochondrion, both a source and target of oxidants related to CVD development, has garnered attention. ${ }^{61-73}$

\section{THE MECHANISMS OF INDIVIDUAL CVD SUSCEPTIBILITY ARE NOT CLEARY UNDERSTOOD}

While significant progress in understanding the pathology, progression, and development of CVD has been made, the determinants of why some individuals with identical CVD risk factor profiles develop disease while others will not are not clearly understood. Currently, $<5 \%$ of CVD appears to result from single mutations, such as those regulating lipoprotein synthesis. ${ }^{74,75}$ It has been estimated that $70-80 \%$ of CVD is attributable to modifiable, non-genetic factors, which is consistent with the notion that environmental factors heavily influence the risk of disease development. ${ }^{74}$ In addition to endogenous and environmental risk factors (ie, hypercholesterolemia and tobacco smoke exposure, respectively), CVD susceptibility is also increased by age, family history, ${ }^{76-81}$ and ethnicity (reviewed in Forouhi and Sattar ${ }^{82}$ ). Some studies have shown that differences in cardiovascular function exist between racial groups; however, the basis of these differences is currently unclear. ${ }^{83-88}$ Consequently, it is thought that CVD is a multifactorial disorder that involves both environmental and genetic factors. ${ }^{89,90}$ A corollary of this idea, however, is that individual response to environmental factors can be genetically influenced.

The Mendelian concept, or the 'common disease, common variants' hypothesis suggests that common forms of disease such as CVD have a multifactorial and polygenic basis: genetic variants present in many normal individuals, each with a relatively small effect, alone, or in combination with modifier genes and environmental factors contribute to overall CVD risk. ${ }^{89,90}$ Hence, it has been hypothesized that multiple genes involved in vascular regulation, lipoprotein metabolism, inflammation, metabolic control, and redox tone (the balance between oxidant generation and neutralization by antioxidants) and their interaction with risk factors influence CVD susceptibility. ${ }^{77,78}$ In this regard, studies have looked for connections between polymorphic gene mutations and CVD development. However, many original associations were lost in larger-scale studies, or were not as predictive for risk as plasma markers such as cholesterol levels. ${ }^{75,91-97}$ Consequently, while important in advancing the understanding of gene 'groups' that may be involved in influencing predilection to disease development, the underlying genetic and physiologic basis of why these differences exist is not well understood.

Because CVD usually develops over decades, its etiology should entail subtle changes in the vascular/endothelial environment over time, collectively resulting in the initiation and progression of disease. Therefore, features of CVD development should involve genetic and cellular mechanisms that (i) have important roles in multiple cell functions involving the regulation and expression of multiple genes (eg, growth, death, signaling, and bioenergetics); (ii) are capable of gradual decline or dysfunction over time (an 'aging' mechanism); (iii) are susceptible to oxidative damage (risk factors); and (iv) explain risk associated with ethnicity.

The mitochondrion and its genome may account for these features in CVD development. The mitochondrion (i) is a multifunctional organelle, which is a central focal point for proper cell function due to its role in energy production, cell growth, apoptosis, thermogenesis, and redox signaling ${ }^{98-102}$; (ii) has an 'aging' mechanism - there are thousands of copies of mitochondrial DNA (mtDNA) per cell, allowing for the accumulation of mtDNA mutations and damage over time that cause an age-related decline in mitochondrial function $^{103,104}$; (iii) is vulnerable contemporary CVD risk factors and oxidative stress, which increase mitochondrial damage and alter function in cardiovascular tissues ${ }^{61-64}$; and (iv) harbors the mtDNA, which displays marked regional variation and has proven useful in population and molecular anthropological studies. ${ }^{105}$ By contrast, most ancient nDNA polymorphisms are common to all global populations. ${ }^{106}$ Similarly, maternal family history of CVD has also been reported to convey greater risk than paternal history. ${ }^{77-81}$ Although this association is controversial and has been suggested to be due to offspring-maternal nutritional effects that 
were experienced in utero, ${ }^{107,108}$ studies of in utero risk factor exposure have shown mtDNA damage.$^{64}$ Consequently, these observations are consistent with the notion that mitochondria have significant roles in the etiology of CVD.

\section{MITOCHONDRIA ARE MULTIFUNCTIONAL ORGANELLES}

Mitochondria are ancient bacterial endosymbionts with their own DNA, RNA, and protein synthesis systems. ${ }^{109}$ Mitochondria are multifunctional organelles, and serve as the sites for electron transport, oxidative phosphorylation (OXPHOS), the citric acid cycle, $\beta$-oxidation, steroidogenesis, and many other important cellular functions including growth, oxidant generation, and programmed cell death. ${ }^{102}$ In fact, the primary function of the mitochondrion is dependent upon the current requirements and environment of the cell. For instance, the primary function of a mitochon- drion within an endothelial cell may be the regulated generation of oxidants for cell signaling, whereas within a cardiac myocyte, it may be the generation of ATP, or, a combination of functions therein (eg, ATP and oxidant generation). This unique feature of mitochondrial functional biology makes it the central focal point in terms of the mechanistic basis of many forms of age-related diseases, including CVD.

Mitochondria fundamentally execute the conversion of caloric energy into molecular energy, thermal energy, and oxidants (Figure 1). They achieve these tasks by coupling electron transport with proton translocation and OXPHOS. The energy released during the movement of electrons along the electron transport chain (ETC) is used to pump protons across the inner membrane at complexes I, III, and IV, which creates a transmembrane electrochemical gradient. This
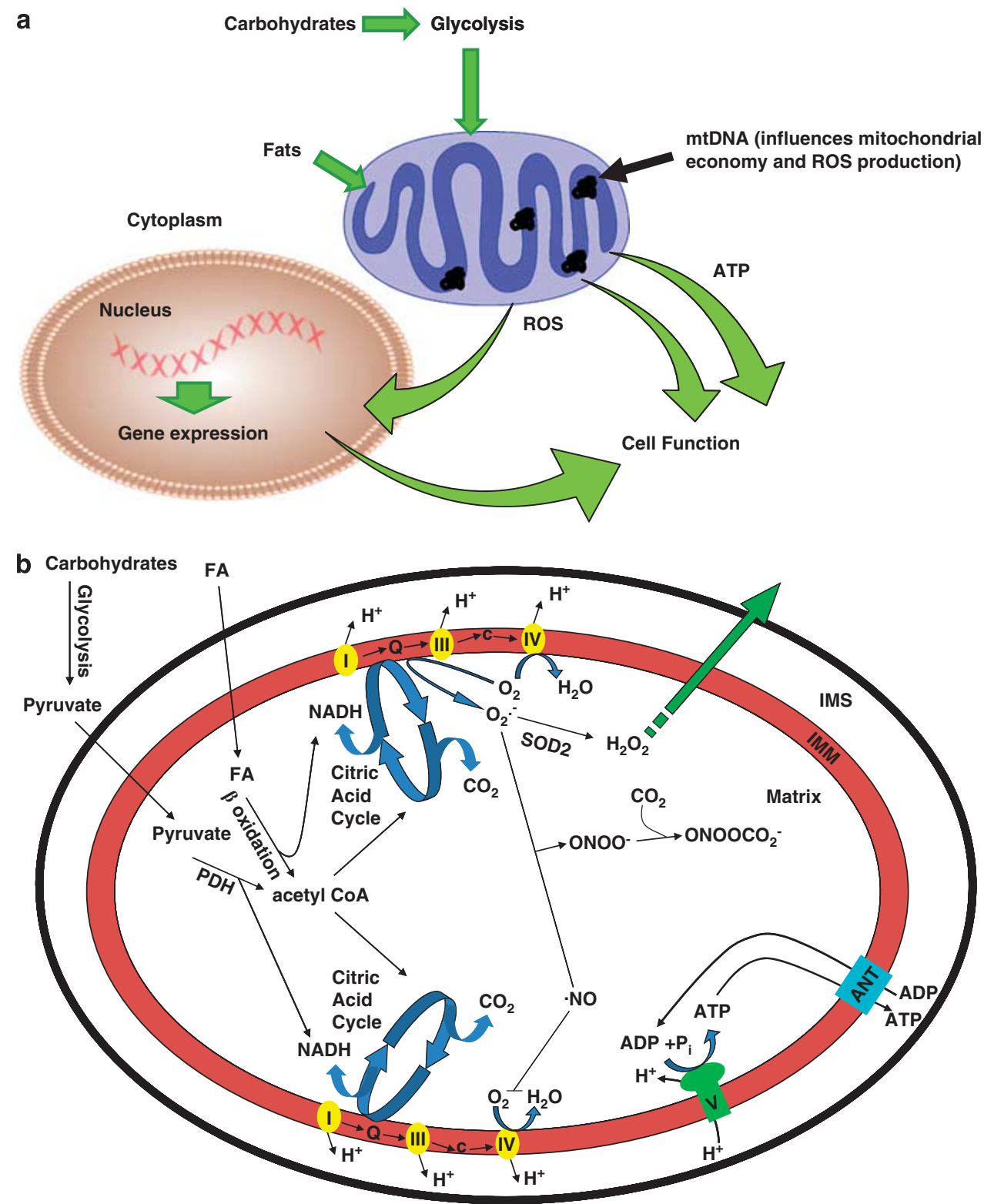
potential energy is utilized by ATP synthase (complex V) to condense ADP and $\mathrm{P}_{\mathrm{i}}$ to form ATP. The energy not utilized for proton pumping is lost in the form of heat (thermogenesis). Electrons are also donated directly to oxygen $\left(\mathrm{O}_{2}\right)$ during electron transport to form superoxide $\left(\mathrm{O}_{2}{ }^{-}\right)$, which can be converted to hydrogen peroxide $\left(\mathrm{H}_{2} \mathrm{O}_{2}\right)$ and contribute to cell redox signaling processes, or in the presence of nitric oxide ( $\cdot \mathrm{NO})$, form peroxynitrite $\left(\mathrm{ONOO}^{-}\right)$, an oxidant that can react with carbon dioxide $\left(\mathrm{CO}_{2}\right)$ to form nitrosperoxycarbonate $\left(\mathrm{ONOOCO}_{2}^{-}\right)$, a nitrating agent. ${ }^{24,110}$

Each cell contains hundreds to thousands of mitochondria and each mitochondrion contains 5-10 copies of maternally inherited mtDNA. The mammalian mtDNA encodes 13 polypeptides, two rRNAs (12S and 16S) and 22 tRNAs that are essential for OXPHOS and proper cell function (Figure 2). The nucleus encodes all the remaining mitochondrial proteins for the organelle. Interestingly, the mtDNA retained key structural subunits required for the catalytic activity for four of the five OXPHOS enzyme complexes (I, III, IV, and V). Consequently, mutations in these mtDNA-encoded subunits could alter features in mitochondrial metabolism or economy (bioenergetic function).

\section{MITOCHONDRIAL ECONOMY}

Mitochondrial economy describes how the organelle utilizes the oxygen it consumes in terms of molecular (ATP) and thermal energy production, plus oxidant generation. This economy is therefore dependent upon a myriad of factors including local concentrations of both reactive nitrogen and oxygen species, mitochondrial antioxidants, cytokines, electron transport efficiency, metabolic reducing equivalent availability $\left(\mathrm{NADH}, \mathrm{FADH}_{2}\right.$, and those from $\beta$-oxidation of fatty acids), cellular energetic demand, uncoupling protein (UCP) activities, and overall organelle integrity (damage to membranes, DNA, and proteins). Among these factors, electron transport efficiency as it relates to overall ' $m$ itochondrial economy' has received limited attention and has not been considered seriously in relation to CVD development. Mitochondria that utilize less oxygen to generate the same amount of ATP compared with mitochondria that use more oxygen for ATP production are, relatively speaking, more economical. Hence, economical mitochondria will have a higher ATP $/ \mathrm{O}_{2}$ compared with those that are relatively less economical. Under conditions of excess substrate and low energetic demand (positive energy balance), mitochondria with high ATP $/ \mathrm{O}_{2}$ will have a greater proportion of electron carriers in a reduced state (occupied by electrons) compared with those with lower ATP/O $\mathrm{O}_{2}$ and thus, will be more prone to donate electrons to oxygen to form oxidants and are suggested to include African haplotypes (Figure 3, higher mitochondrial economy). However, under chronic conditions of substrate excess and low energetic demand, even mitochondria that are less economical will generate increased oxidants. Mitochondria with low ATP $/ \mathrm{O}_{2}$ utilize more electrons and $\mathrm{O}_{2}$ to generate ATP, resulting in greater energy loss in the form of heat compared with those with higher ATP $/ \mathrm{O}_{2}$ and are suggested to include Eurasian and northern migratory haplotypes (Figure 3, lower mitochondrial economy).

\section{PREHISTORIC SELECTION, MITOCHONDRIAL ECONOMY, AND EVOLUTION}

As humans migrated from Africa, they encountered changes in climate and diet as they moved northward. ${ }^{111,112}$ To successfully survive and reach reproductive age, it was necessary to develop a biological system to deal with these

Figure 1 (a) Fundamental aspects of mitochondrial function. Caloric energy (carbohydrates and fats) is converted into molecular (ATP) and thermal (heat, energy lost during electron transport) energy and oxidants (reactive oxygen species (ROS)). While ATP is utilized for energy requiring cell functions, mitochondrial generated ROS influence redox cell signaling processes, including induction of nuclear gene expression (via redox sensitive transcription factors), which contribute to cell function. Differences in mtDNA sequences are proposed to influence mitochondrial oxygen utilization (economy) and ROS production that impact cell function. The conversion of caloric energy into these respective components is dependent on overall organelle economy (influenced by the mtDNA-encoded subunits), degree of positive or negative energy balance, and uncoupling proteins. ATP and ROS are utilized for cellular functions (energy requiring processes and redox signaling); mitochondrial ROS also serve as a means for communication to the nuclear compartment and regulation of certain nuclear genes. (b) Carbohydrates are metabolized to glucose that is further converted to pyruvate (glycolysis) in the cytoplasm and transported into the mitochondrion. Acetyl $\mathrm{CoA}$ is formed from pyruvate via oxidative decarboxylation (pyruvate dehydrogenase), where it enters the citric acid cycle that yields reducing equivalents ( $\mathrm{NADH}$ and $\mathrm{FADH} 2$ ) for electron transport located within the mitochondrial inner membrane. $\mathrm{NADH}$ is oxidized at complex I (NADH:coenzyme Q oxidoreductase or NADH dehydrogenase) of the transport chain while FADH is oxidized at complex II (succinate:coenzyme Q oxidoreductase or succinate dehydrogenase, part of the citric acid cycle). Electrons are next passed to coenzyme $Q$ (Q). Complex III (coenzyme

$\mathrm{Q}$ :cytochrome $\mathrm{c}$ oxidoreductase or cytochrome $b c_{1}$ complex) passes electrons from reduced coenzyme $\mathrm{Q}(\mathrm{Q})$ to cytochrome $c(\mathrm{c})$, a peripheral membrane protein that alternately binds cytochrome $\mathrm{cl}$ (of complex III) and to complex IV (cytochrome coxidase). Complex IV catalyzes the one electron oxidations of four consecutive reduced cytochrome c molecules and the concomitant four electron reduction of one $\mathrm{O}_{2}$ molecule to yield $\mathrm{H}_{2} \mathrm{O}$. During electron transport, protons are pumped across the inner membrane from the matrix into the intermembrane space, creating an electrochemical gradient. The free energy resulting from this gradient is utilized to condense a molecule of inorganic phosphate $\left(P_{i}\right)$ with ADP at complex V (ATP synthase or $\left.F_{1} F_{0}-A T P a s e\right)$ to yield ATP. ATP is subsequently transported out of the matrix by the inner membrane bound adenine nucleotide translocase (ANT) with the exchange of ADP. Fats bypass glycolytic metabolism in the cytoplasm and undergo $\beta$-oxidation in the mitochondrion to yield acetyl CoA (plus NADH and FADH2 per cycle of oxidation), which enters the citric acid cycle to generate substrates for electron transport. During electron transport, superoxide $\left(\mathrm{O}_{2}{ }^{-}\right)$is generated when electrons are added to $\mathrm{O}_{2} ; \mathrm{O}_{2}{ }^{--}$is converted to hydrogen peroxide $\left(\mathrm{H}_{2} \mathrm{O}_{2}\right)$ in the mitochondrion by manganese superoxide dismutase (MnSOD or SOD2). $\mathrm{H}_{2} \mathrm{O}_{2}$ (which is freely diffusible) can participate in cell signaling processes $\left(\mathrm{H}_{2} \mathrm{O}_{2}\right.$ levels are regulated by a number of antioxidants within the mitochondrion and the cell, not illustrated). Alternatively, $\mathrm{O}_{2} \cdot-$ reacts with nitric oxide ('NO) to form peroxynitrite $\left(\mathrm{ONOO}^{-}\right)$, an oxidant, which in the presence of carbon dioxide $\left(\mathrm{CO}_{2}\right)$ forms nitrosoperoxycarbonate $\left(\mathrm{ONOOCO}_{2}^{-}\right)$, a nitrating agent. 


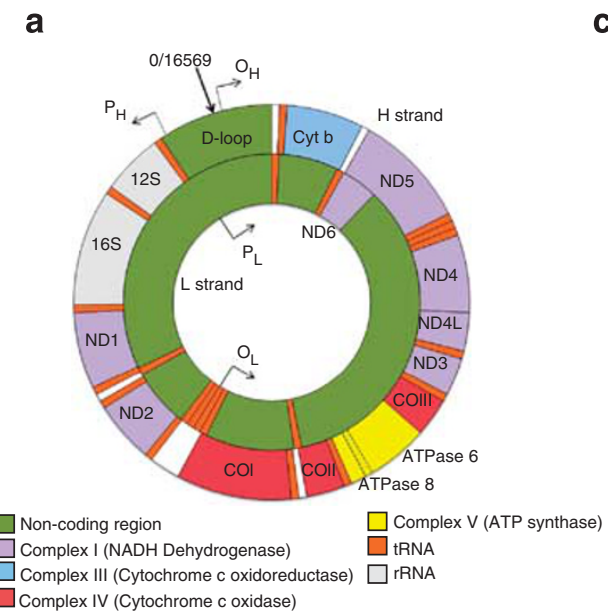

b

\begin{tabular}{|c|c|c|c|c|c|c|}
\hline \multicolumn{1}{|c|}{ Complex } \\
\hline$\underline{\text { Genome }}$ & $\underline{I}$ & $\underline{I}$ & $\underline{\mathbf{I I}}$ & $\underline{\mathbf{I V}}$ & $\underline{\mathbf{V}}$ & $\underline{\underline{T}}$ \\
\hline mtDNA & $\mathbf{7}$ & 0 & 1 & 3 & 2 & 13 \\
\hline nDNA & 38 & 4 & 10 & 10 & 14 & 76 \\
\hline Total & $\mathbf{4 5}$ & $\mathbf{4}$ & $\mathbf{1 1}$ & $\mathbf{1 3}$ & $\mathbf{1 6}$ & $\mathbf{8 9}$ \\
\hline
\end{tabular}

c

\begin{tabular}{|c|c|c|}
\hline Complex & $\begin{array}{l}\text { mtDNA } \\
\text { encoded } \\
\text { gene }\end{array}$ & Comments \\
\hline 1 & ND1 & Quinone binding subunit \\
\hline 1 & ND2 & Proton translocating subunit \\
\hline I & ND3 & Membrane subunit/transporter \\
\hline I & ND4 & Proton translocating subunit \\
\hline I & ND4L & Membrane subunit/transporter \\
\hline I & ND5 & Ion translocating subunit \\
\hline 1 & ND6 & Membrane subunit/transporter \\
\hline III & Cyt b & $\begin{array}{l}\text { Receives } e^{-} \text {from ubiquinone and } \\
\text { donates to Reiske protein }\end{array}$ \\
\hline IV & $\mathrm{COI}$ & $\begin{array}{l}\text { Catalytic subunit, reduces } \mathrm{O}_{2} \text { to } \mathrm{H}_{2} \mathrm{O} \text {, } \\
\text { receives } \mathrm{e}^{-} \text {from } \mathrm{COX} \|\end{array}$ \\
\hline IV & COII & $\begin{array}{l}\text { Catalytic subunit, electrostatically binds } \\
\text { to Cyt c and receives e from Cyt c. }\end{array}$ \\
\hline IV & COIII & $\begin{array}{l}\text { Core structural subunit, may function in } \\
\text { proton pumping }\end{array}$ \\
\hline V & ATPase 6 & $\begin{array}{c}F_{o} \text { subunit, serves to anchor stator, } \\
\text { interacts with ATP IV to form proton } \\
\text { channel }\end{array}$ \\
\hline V & ATPase 8 & $\begin{array}{l}F_{o} \text { subunit, steadies the stator stalk } \\
\text { which stabilizes rotor torque associated } \\
\text { with proton gradient driven rotation }\end{array}$ \\
\hline & 22 tRNAs & Degenerative genetic code \\
\hline & 2 rRNAs & $16 S$ and $12 S$ \\
\hline
\end{tabular}

Figure 2 (a) Sequence organization of the mammalian mtDNA. Colors indicate mtDNA-encoded subunits for respective electron transport complexes, ATP synthase, tRNAs, and rRNAs. ATPase 6 and 8 subunits overlap in sequence. The origins of heavy-strand (guanosine rich) and light-strand DNA synthesis are indicated by $\mathrm{O}_{\mathrm{H}}$ and $\mathrm{O}_{\mathrm{L}}$, respectively. Transcriptional promoters for the heavy and light strands are represented by $\mathrm{P}_{\mathrm{H}}$ and $\mathrm{P}_{\mathrm{L}}$, respectively. The $\mathrm{D}$-loop (displacement loop) is an $\sim 1 \mathrm{~kb}$ non-coding region within the mtDNA. The mtDNA genetic code is highly degenerate, so that only 22 are required for protein translation. When uridine is in the wobble position, all four members of a codon family can be read by one mitochondrial tRNA, whereas pairs of codons can be read when guanine or uridine is in the wobble position. Hence, eight mitochondrial tRNAs recognize four member codon families, while 14 tRNAs recognize codon pairs. (b) Table presenting the number of mtDNA and nDNA-encoded subunits for each electron transport complex (I-IV) and ATP synthase $(V)$ in the mammalian mtDNA. (c) Table summarizing the known (or putative) function of each of the mtDNA-encoded genes.

challenges. Consequently, selective pressures on prehistoric humans were exclusively related to reproductive success and survival of their offspring to reproductive age. Post-reproductive challenges beyond the successful rearing of offspring to reproductive age were not major selective pressures in a genetically adaptive sense. As our ancestors moved northward, they accumulated a greater frequency of mtDNA missense mutations relative to silent substitutions. ${ }^{100,113}$ It has been proposed that these mutations altered aspects of mitochondrial economy that enabled these northern migrants to generate more heat/calorie consumed. ${ }^{99,100,113}$ These changes were tolerated because the diet of these migrants changed from a low-protein, low-fat vegetarian diet to a high-protein, high-fat diet consisting of animal fats ${ }^{111,112}$; hence, the decreased ATP generation/calorie (due to increased heat production) associated with these mtDNAs may have been offset by higher caloric intake. Consequently, by changing aspects of mitochondrial function in settings of warm climates and vegetarian diets to a system designed to be more thermogenic in a setting of cold climates with increased caloric intake, these changes in mitochondrial function may have contributed to increased probability for survival of the young to reproductive age.

Changes in mitochondrial function and/or protein levels associated with specific animal adaptations in vertebrates have been previously noted. For example, hibernating 13lined ground squirrels (Spermophilus lateralis) demonstrate upregulated nad2 (mitochondrial-encoded ETC complex I subunit) mRNA in heart, liver, and skeletal muscle during hibernation ${ }^{114}$ coincidental with $95 \%$ decreased metabolic rate compared with resting levels and decreased core body temperature maintained below $10^{\circ} \mathrm{C} .{ }^{115}$ Smaller mtDNAencoded cytochrome $b$ and $c$ spectra in S. lateralis liver mitochondria have also been reported during hibernation, which may decrease the capacity of complex III $^{116}$ affecting ROS formation and CVD, ${ }^{117} \mathrm{mtDNA}$ damage, and retrograde signaling (discussed below in 'The implications of the mitochondrial paradigm .... and disease development'). In an avian model, the bar-headed goose (Anser indicus) that migrates over the Himalayas (altitudes up to $9000 \mathrm{~m}$ ) must sustain high metabolic rates in the context of severe hypoxia. A. indicus has evolved more subsarcolemmal mitochondria bordering capillaries with increased densities within increased numbers of oxidative fibers, enabling them to sustain high metabolic rates for flight under hypoxic conditions compared with low-altitude birds. ${ }^{118}$ This evolutionary adaptation to hypoxia has more recently been shown to involve decreased maximal cytochrome $\mathrm{c}$ oxidase (COX) activity, a higher affinity of COX for reduced cytochrome c, and proportional decreases in COX3/COX1 and COX4/ 


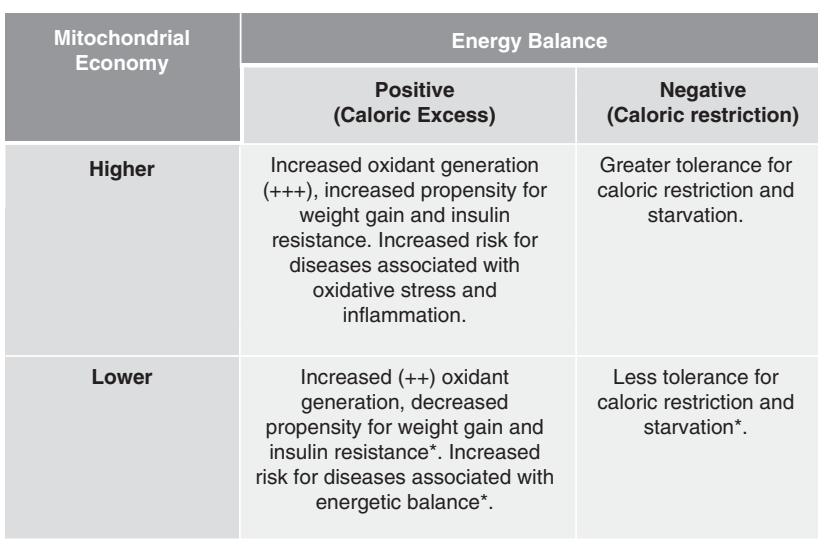

Figure 3 Table summarizing the anticipated characteristics of cells/tissues/ individuals harboring mitochondria having higher or lower economy in regard to cellular-tissue oxidant generation and individual propensity for weight gain under positive or negative energy balance. An asterisk $\left({ }^{*}\right)$ indicates relative to higher economy; however, under conditions of persistent positive energy balance, even cells/tissues/individuals with decreased (lower) mitochondrial economy will exhibit the same features as those with higher economy due to chronic stress. It is predicted that these features will be related to specific mtDNA sequences, or shared mutations between mtDNA haplotypes (representing mtDNA haplogroups).

COX3 protein expression. The decreased COX3 subunit (mtDNA encoded) in the bar-headed goose also has a nonsynonymous substitution at a conserved site in vertebrates, which based on structural modeling suggests it would alter the interactions of COX3 and COX1 accounting for the increased economy and evolutionary mechanisms of high-altitude adaptation. ${ }^{119}$ Finally, although not extensively studied, aspects of adaptive evolution of the mtDNAencoded subunits across placental mammals has been examined, potentially providing a framework for future characterization of mtDNA mutations in regard to their impact on cellular function and physiology. ${ }^{120}$

\section{MITOCHONDRIAL OXIDANT PRODUCTION}

The perception that mitochondrial oxidant production is analogous to 'pollution' or an unnecessary by-product of electron transport is inaccurate. While many reports have implicated mitochondrial oxidant generation as an important form of cellular stress that contributes to disease development, which is certainly a correct interpretation, ${ }^{65,66,68,70,72,121-145}$ it also reflects a contemporary viewpoint. Mitochondrial produced oxidants most likely originally served as a signaling system for the benefit of the host (the eukaryotic cell), a concept that has not been widely contemplated. From an evolutionary perspective, the cellular functions of the mitochondrion developed over millions of years of endosymbiosis with its nucleated host. Because it is possible that our protoeukaryotic ancestors spent a significant amount of time during their evolutionary existence under conditions of limited caloric availability, they likely evolved systems of mitochondrial-nuclear interactions designed for increased survival and reproductive success under conditions of punctuated caloric restriction. Consequently, selection for a system that had a rapid feedback/signaling mechanism (production of oxidants) linked to energy production that would induce caloric storage when energetic demands were met would be strong. This notion would suggest that mitochondrial oxidants may have originally served as stimuli for (i) insulin production and (ii) signaling molecules for insulin signaling pathways in non-insulin producing tissues. Hence, the mitochondrial oxidants may have initially served as a means for regulating caloric utilization and storage. Under conditions of excess substrate and low cellular energetic requirements (positive energy balance), mitochondria would increase oxidant production, triggering signaling pathways that would have led to storage of calories. ${ }^{146-150}$ As energy demand increased or food availability became low, mitochondrial oxidant production would decrease, as would caloric storage pathways. In this regard, studies have shown that mitochondrial oxidant generation or the alteration of mitochondrial UCP levels can impact insulin secretion and also affect aspects of insulin sensitivity. ${ }^{68,147,151,152}$ While many studies have also shown that mitochondrial oxidant production inhibits insulin production and sensitivity, these studies are often performed under chronic conditions of hyperglycemia and therefore represent contemporary stress factors rather than prehistoric. Regardless, studies have shown that a connection exists between mitochondrial oxidant production and insulin secretion, ${ }^{153,154}$ and more recent work suggests that oxidants impact insulin signaling pathways in non-insulin producing tissues. ${ }^{146,155,156} \mathrm{~A}$ final consideration is that these systems were designed to increase survival for reproductive purposes and hence, may function more robustly in the young (by virtue of their importance for survival and from a gene pool perspective). This concept is supported by the observation that insulin sensitivity is higher in the young compared with old. ${ }^{157}$

\section{THE IMPLICATIONS OF THE MITOCHONDRIAL PARADIGM FOR CONTEMPORARY SOCIETY AND CONCEPTS OF DISEASE DEVELOPMENT}

As previously discussed, it has been hypothesized that mtDNA mutations fixed into prehistoric populations altered aspects of mitochondrial economy that enabled our ancestors to survive and reproduce at different geographic latitudes and diets. ${ }^{100}$ Today, these variants in mitochondrial function may influence individual disease susceptibility due to differences in mitochondrial oxidant production related to mtDNA haplotype. ${ }^{100,158}$ With the development of greater physical inactivity, increased lifespan and excessive caloric intake seen in Western societies, these variants in mitochondrial function and genetics may influence predisposition toward disease development. Individuals with greater mitochondrial economy will have increased basal 
levels of endogenous mitochondrial oxidant stress under conditions of excessive caloric intake, physical inactivity (positive energy balance, Figure 3), and exposure to CVD risk factors compared to those with less economy and thus, will appear more susceptible to diseases related to oxidative stress such as CVD. Furthermore, those individuals with less mitochondrial economy will appear less susceptible to diseases related to oxidative stress, yet will not be completely immune to such disease under conditions of high caloric intake and/ or physical inactivity (Figure 3). Chronic, excessive caloric intake and low energetic demands will still result in sustained mitochondrial oxidant generation over time that will induce cellular damage; hence even those individuals with lower mitochondrial economy will potentially develop CVD or cardiometabolic diseases with persistent exposure to these stressors. Conversely, individuals harboring mitochondria with greater economy will be more tolerant toward caloric restriction compared with those having less economy (Figure 3, negative energy balance). This of course, sets up the dilemma that individuals more prone for weight gain under conditions of positive energy balance will be also more resistant to weight loss under conditions of negative energy balance although it has been shown that regular steady exercise may prevent or diminish the influence of mtDNA haplotype on some physiologic measures including aerobic capacity $^{159}$ and ROS-induced damage to skeletal muscle. ${ }^{160}$

Evidence supporting these concepts is becoming recognized; several studies have shown that specific mtDNA mutations and haplotypes are associated with differences in oxygen consumption, increased risk for diseases thought or known to have an environmental component (eg, deafness, blindness, Alzheimer's disease, diabetes, and cancer). ${ }^{104,160-181}$ Similarly, studies have shown that the mtDNA haplotype can influence tumor growth and agerelated deafness in mice. ${ }^{182,183}$ It has also been suggested that human longevity significantly co-segregates with mtDNA haplotypes that have temperate and arctic origins, ${ }^{174,175}$ yet they may have increased predilection for clinical illnesses associated with energetic insufficiencies such as blindness and CNS defects. ${ }^{100}$ Alternatively, mitochondrial haplotypes thought to be associated with increased mitochondrial economy may be more prone to certain types of cancer and age-related diseases associated with oxidative stress and/or somatic mutation. ${ }^{100,182}$ More recent studies suggest a link between mtDNA haplotypes and CVD in certain populations. ${ }^{184}$ While studies in cybrid culture have provided conflicting results regarding the concept that the mtDNA influences cellular bioenergetics, ${ }^{158,185-187}$ studies in conplastic strains of mice suggest that mtDNA background influences aspects of cognition, behavior, reproductive behavior, and susceptibility to autoimmune disease. ${ }^{188-191}$ An extension of the concept that the mtDNA alters organelle economy (bioenergetics), which influences disease susceptibility, is that it may also have a role in modulating nuclear gene expression since the majority of proteins functioning within the mitochondrion are encoded by the nucleus. If this is the case, it would represent another historical clue regarding the evolution of the eukaryotic cell and endosymbiosis, and thus, provide the basis for an additional paradigm in that the mtDNA influences the selection of certain nuclear-mitochondrial gene combinations and mitochondrial retrograde signaling. ${ }^{192-194}$ If true, this would have serious implications regarding the use of transgenics derived from different strains of mice (eg, backcrossing one strain on the background of another) and there are likely to be tissue-specific effects on mitochondrial-nuclear signaling ${ }^{195-197}$ influenced by energy balance, ROS, exercise, and diet.

\section{THE ROLE OF DIET AND MITOCHONDRIAL FUNCTION}

The composition and caloric content of the diet likely influence mitochondrial and cellular interactions. Excessive caloric intake without increased energy expenditure (a net positive energy balance) will result in increased weight gain, oxidant stress, and disease risk. While the effects of positive energy balance on mitochondrial function are a matter of debate concerning the question of whether mitochondrial dysfunction or positive energy balance drives the development of insulin resistance, diabetes, and cardiometabolic diseases, ${ }^{198-202}$ it is evident that caloric restriction decreases mitochondrial oxidant production and cardiovascular risk. ${ }^{203-205}$ Interestingly, it has also been shown that methionine restriction without caloric restriction can decrease mitochondrial oxidant production and mtDNA damage in rodents, ${ }^{206-208}$ while the same percent of carbohydrate does not. $^{209,210}$ In contrast, methionine supplementation in rats has been shown to increase ROS production and mtDNA damage in rat liver but not the heart. ${ }^{211}$ Diets with higher unsaturated/polyunsaturated fat content (ie, fats from natural vegetable oils, nuts, and fish) compared to those with higher saturated fat (pork, beef, chicken, dairy, eggs, coconut oil, and some seafood) have been shown to decrease $\mathrm{CVD},{ }^{212-215}$ and decrease mitochondrial ROS production. ${ }^{216}$ Polyphenols such as resveratrol contained in red grapes, red wine, and peanuts have been shown to induce mitochondrial biogenesis through activation of sirtuin-1 (NAD-dependent deacetylase sirtuin-1 or SIRT1) and peroxisome proliferatoractivated receptor $\gamma$ coactivator $1-\alpha$ (PGC- $1 \alpha),{ }^{217}$ improving health, survival, and decreasing diabetic complications. ${ }^{218,219}$ Coincidental with dietary and mitochondrial interactions are conflicting reports regarding low-carbohydrate $v s$ low-fat diets and their effects on disease progression. Ketogenic diets, high-fat with adequate protein and low-carbohydrates, mimic caloric restriction by forcing the body to burn fats rather than carbohydrates and have been shown to decrease mitochondrial ROS production through increased NADH oxidation. ${ }^{220}$ Ketogenic diets are clinically used to treat many acute and chronic neurological diseases such as stroke, ${ }^{221}$ epilepsy, ${ }^{222,223}$ mitochondrial myopathy, ${ }^{224}$ and CVD. ${ }^{225}$

The interaction of diet on mitochondrial function and bioenergetics in general involves the capability of the 
mitochondria to effectively and rapidly signal to the cell that excess reducing equivalents exist (high cytosolic NADH/ $\mathrm{NAD}+$ and ATP/AMP). This has been shown to occur in both rodents and humans through low level mitochondrial ROS generation. ${ }^{146,226}$ Hoehn et al ${ }^{146}$ also demonstrated increased MnSOD expression improved glucose and insulin tolerance in mice fed high-fat diets compared with controls. Further, evidence from that study suggests that mitochondrial ROS production (which would be higher under conditions of excess reducing equivalent availability and low ATP demand) may serve as a cell signal that decreases GLUT4 translocation to the cellular plasma membrane and induces temporary insulin resistance (by limiting cellular glucose uptake) in adipocytes and myotubes. ${ }^{146}$ Decreased influx of glucose would decrease NADH/NAD +, increase AMP/ATP, stimulate increased flux of electrons through the ETC, decrease membrane potential, and decrease ROS formation. However, under conditions of persistent positive energy balance, individuals with increased adiposity would also supply reducing equivalents via $\beta$-oxidation, and chronic ROS formation would ensue, contributing to post-translational oxidation of lipids, proteins and mtDNA, downregulation of metabolism, and vicious cycle of ROS-mediated mitochondrial dysfunction.

Under positive energy balance, excess reduced carbohydrates, fats, and other foodstuffs lead to a chronic cellular redox shift toward an overload of reduced cytosolic NADH creating a 'reductive stress. ${ }^{227}$ Elevated levels of these high energy electron carriers, $\mathrm{NADH}$, and the reduced form of flavin adenine dinucleotide, FADH2, would come from glycolysis and the Krebs cycle. Under these circumstances, most dehydrogenases and all NAD +-dependent enzymes would function abnormally because of the relative deficiency of $\mathrm{NAD}+$ and inhibitory feedback mechanisms well described in most biochemistry textbooks. The NADH/NAD varies in response to changes in metabolism ${ }^{228-230}$ and is often used as a measure of the intracellular redox or metabolic state of the organism. ${ }^{231}$ Since NADH cannot penetrate the inner mitochondrial membrane directly, various shuttling mechanisms exist to transport the NADH reducing equivalents into the mitochondria for oxidation. The malate-aspartate shuttle is required in yeast for increased life span mediated through calorie restriction. ${ }^{232}$ Mitochondrial glycerol-3-phosphate shuttle also helps to funnel cytosolic reducing equivalents to the mitochondria for respiration ${ }^{233}$ and when knocked out in plants has been shown to increase the NADH/NAD ratio. ${ }^{234}$

Carbohydrate metabolism generates a ratio of $5 \mathrm{NADH} /$ FADH2 (per pyruvate), while fat metabolism generates a ratio of $2 \mathrm{NADH} / \mathrm{FADH} 2$ (per acetyl CoA), which feed into the ETC at complex I for NADH and succinate dehydrogenase (complex II) for FADH2. These reducing equivalents converge on coenzyme $\mathrm{Q}$ and complex III. Mitochondrial oxidant production has been shown to originate from complexes I and III of the ETC ${ }^{235-239}$ through both forward and reverse electron flux. ${ }^{240,241}$ Hence, under conditions of excess reducing equivalents and low energy demand (positive energy balance), a 'bottleneck' can occur at coenzyme Q and complex III that increases cytosolic NADH/ $\mathrm{NAD}+$, mitochondrial membrane potential, and ROS formation. ${ }^{242}$ Moreover, it is possible that these effects are compounded in overweight individuals by virtue of their increased adiposity, which further contributes to reducing equivalent availability through $\beta$-oxidation. Consistent with the notion that coenzyme Q may have an important role in modulating the effects of excess reducing equivalent availability are reports that mitochondrially targeted coenzyme Q supplementation protects against endogenous oxidative stress $^{243}$ and that supplementation of CoQ has helped alleviate myopathic symptoms. ${ }^{244}$ Interestingly, coenzyme Q deficiency may exacerbate cardiometabolic, ${ }^{245}$ neurologi$\mathrm{cal}^{246}$ and other diseases including diabetes and cancer. ${ }^{247} \mathrm{It}$ has also been reported that coenzyme Q deficiency induces mitochondrial degradation by mitophagy. ${ }^{248}$

\section{SUMMARY}

While there has been significant progress in understanding the pathological processes involved in CVD progression and development, the continuing status of CVD as the leading cause of death and morbidity in the Western world for the past century implies a lack of understanding regarding the basis of individual CVD susceptibility. Numerous studies have delineated important CVD risk factors, and although there is general agreement that they share a common feature of increasing vascular oxidant stress, the actual mechanistic basis of how they initiate or promote CVD development in some individuals and not in others with identical risk profiles is not clearly understood. It is widely thought that CVD development is influenced by a combination of genetic, environmental, and behavioral factors that influence an individual's biological response to known disease risk factors. A consideration currently lacking from these analyses is the potential role for mitochondrial genetics and function in determining CVD susceptibility. The mitochondrion is directly involved in the inter-relative aspects of caloric conversion to energy, thermogenic output, and oxidant production, and has been previously shown in numerous studies to be associated with cardiovascular dysfunction. Another aspect not commonly considered is that mitochondrial-nuclear relationships were established millions of years ago and were likely refined during prehistoric environmental selection events that today are largely absent. By contrast, contemporary risk factors that influence our susceptibility to a variety of age-related diseases, including CVD were probably not part of the 'equation' so to speak, that defined the processes of mitochondrial-nuclear interaction. Consequently, these diseases that are mostly postreproductive are the by-product of our rapidly changing environment induced by technology; an environment for which our eukaryotic system was not designed. In this regard, the selective conditions that contributed to cellular 
functionality and evolution should be given more consideration when interpreting and designing experimental data and strategies. Finally, future studies that probe beyond epidemiologic/molecular epidemiologic associations are required. These studies will serve as the initial steps for addressing the provocative concept that contemporary human disease susceptibility is the result of selection events for mitochondrial function that increased chances for prehistoric human survival and reproductive success.

\section{ACKNOWLEDGEMENTS}

This study was funded by NIH Grants HL77419, HL94518, P60 DK79626, NIH training grants in Cardiovascular Pathophysiology (T32 HL007918) and Hypertension (T32 HL007457), an American Heart Association predoctoral fellowship (09PRE2240046), and the Howard Hughes Med-to-Grad Program fellowship (56005705).

\section{DISCLOSURE/CONFLICT OF INTEREST}

The authors declare no conflict of interest.

1. American Heart Association. Heart disease and stroke statistics - 2006 update. Circulation 2006;105:1-67.

2. Carpenter KL, Taylor SE, van der Veen C, et al. Evidence of lipid oxidation in pulmonary artery atherosclerosis. Atherosclerosis 1995;118:169-172.

3. Halliwell B. Free radicals, reactive oxygen species and human disease: a critical evaluation with special reference to atherosclerosis. Br J Exp Pathol 1989;70:737-757.

4. Halliwell B. Lipid peroxidation, antioxidants and cardiovascular disease: how should we move forward? Cardiovasc Res 2000;47:410-418.

5. Berliner JA, Heinecke JW. The role of oxidized lipoproteins in atherogenesis. Free Radic Biol Med 1996;20:707-727.

6. Massaeli H, Pierce GN. Involvement of lipoproteins, free radicals, and calcium in cardiovascular disease processes. Cardiovasc Res 1995;29:597-603.

7. Freeman $\mathrm{BA}$, White $\mathrm{CR}$, Gutierrez $\mathrm{H}$, et al. Oxygen radical-nitric oxide reactions in vascular diseases. Adv Pharmacol 1995;34:45-69.

8. Steinberg $\mathrm{D}$, Parthasarathy $\mathrm{S}$, Carew $\mathrm{TE}$, et al. Beyond cholesterol. Modifications of low-density lipoprotein that increase its atherogenicity. N Engl J Med 1989;321:1196-1197.

9. Witztum JL, Steinberg D. Role of oxidized low density lipoprotein in atherogenesis. J Clin Invest 1991:88:1785-1792.

10. Reid V, Mitchinson MJ, Skepper J. Cytotoxicity of oxidised low density lipoprotein to mouse peritoneal macrophages: an ultrastructural study. J Pathol 1993;171:321-328.

11. Holland JA, Ziegler LM, Meyer JW. Atherogenic levels of low-density lipoprotein increase hydrogen peroxide generation in cultured human endothelial cells: possible mechanism of heightened endocytosis. J Cell Physiol 1996;166:144-151.

12. Ohara $Y$, Peterson TE, Harrison DG. Hypercholesterolemia increases endothelial superoxide anion production. J Clin Invest 1993;91: 2546-2551.

13. Harrison $\mathrm{D}$, Griendling $\mathrm{KK}$, Landmesser $\mathrm{U}$, et al. Role of oxidative stress in atherosclerosis. Am J Cardiol 2003;91:7A-11 A.

14. Diaz MN, Frei B, Vita JA, et al. Mechanisms of disease - antioxidants and atherosclerotic heart disease. N Engl J Med 1997;337:408-416.

15. Cai $\mathrm{H}$, Harrison DG. Endothelial dysfunction in cardiovascular diseases - the role of oxidant stress. Circ Res 2000;87:840-844.

16. Dhalla NS, Temsah RM, Netticadan T. Role of oxidative stress in cardiovascular diseases. J Hypertens 2000;18:655-673.

17. Iuliano L. The oxidant stress hypothesis of atherogenesis. Lipids 2001;36:S41-S44.

18. Chisolm GM, Steinberg D. The oxidative modification hypothesis of atherogenesis: an overview. Free Radic Biol Med 2000;28:1815-1826.

19. Keith $M$, Geranmayegan A, Sole MJ, et al. Increased oxidative stress in patients with congestive heart failure. J Am Coll Cardiol 1998; 31:1352-1356.
20. Holvoet P, Perez G, Zhao Z, et al. Malondialdehyde-modified low density lipoproteins in patients with atherosclerotic disease. J Clin Invest 1995;95:2611-2619.

21. Schmidt AM, Hori O, Chen JX, et al. Advanced glycation endproducts interacting with their endothelial receptor induce expression of vascular cell adhesion molecule-1 (VCAM-1) in cultured human endothelial cells and mice. A potential mechanism for the accelerated vasculopathy of diabetes. J Clin Invest 1995; 96:1395-1403.

22. Hazen SL, Heinecke JW. 3-chlorotyrosine, a specific marker of myeloperosidase-catalyzed oxidation, is markedly elevated in low density lipoprotein isolated from human atherosclerotic intima. J Clin Invest 1997;99:2075-2081.

23. Radi $R$, Rodriguez $M$, Castro $L$, et al. Inhibition of mitochondrial electron transport by peroxynitrite. Arch Biochem Biophys 1994; 308:89-95.

24. Ischiropoulos H. Biological tyrosine nitration: a pathophysiological function of nitric oxide and reactive oxygen species. Arch Biochem Biophys 1998;356:1-11

25. Minetti M, Scorza G, Pietraforte D. Peroxynitrite induces long lived tyrosyl radicals in oxyhemoglobin of red blood cells through a reaction involving $\mathrm{CO}_{2}$ and a ferryl species. Biochemistry 1999;38:2078-2087.

26. van Jaarsveld H, Kuyl JM, Alberts DW. Exposure of rats to low concentrations of cigarette smoke increases myocardial sensitivity to ischaemia/reperfusion. Basic Res Cardiol 1992;87:393-399.

27. Alexander RW. Atherosclerosis as disease of redox-sensitive genes. Trans Am Clin Climatol Assoc 1998;109:129-145.

28. Alexander RW. Hypertension and the pathogenesis of atherosclerosis: oxidative stress and the mediation of arterial inflammatory response: a new perspective. Hypertension 1995;25:155-161.

29. Parthasarathy S, Rankin SM. Role of oxidized low density lipoprotein in atherogenesis. Prog Lipid Res 1992;31:127-143.

30. Berliner JA, Navab M, Fogelman AM, et al. Atherosclerosis: basic mechanisms. Oxidation, inflammation, and genetics. Circulation 1995;91:2488-2496

31. Taylor AE, Johnson DC, Kazemi H. Environmental tobacco smoke and cardiovascular disease. Circulation 1992;86:1-4.

32. Glantz S, Parmley W. Passive smoking and heart disease; epidemiology, physiology, and biochemistry. Circulation 1991;83: $1-12$.

33. Steenland K. Passive smoking and the risk of heart disease. JAMA 1992;267:94-99.

34. Glantz S, Parmley W. Passive smoking and heart disease. JAMA 1995;273:1047-1053.

35. Steenland K, Thun M, Lally C, et al. Environmental tobacco smoke and coronary heart disease in the American Cancer Society CPS-II Cohort. Circulation 1996:94:622-628.

36. Rodriguez-Iturbe B, Vaziri ND, Herrera-Acosta J, et al. Oxidative stress, renal infiltration of immune cells, and salt-sensitive hypertension: all for one and one for all. Am J Physiol Renal Physiol 2004;286: F606-F616.

37. Touyz RM, Tabet F, Schiffrin EL. Redox-dependent signalling by angiotensin II and vascular remodelling in hypertension. Clin Exp Pharmacol Physiol 2003:30:860-866.

38. Wilcox CS. Oxidative stress and nitric oxide deficiency in the kidney: a critical link to hypertension? Am J Physiol Regul Integr Comp Physio 2005;289:R913-R935.

39. Cohen RA, Tong $X-Y$. Vascular oxidative stress: the common link in hypertensive and diabetic vascular disease. J Cardiovasc Pharmacol 2010;55:308-316.

40. Alberti KG, Zimmet $P$, Shaw J. Metabolic syndrome-a new worldwide definition. A Consensus Statement from the International Diabetes Federation. Diabet Med 2006;23:469-480.

41. National Cholesterol Education Program N. Third report of the national cholesterol education program (NCEP) expert panel on detection, evaluation, and treatment of high blood cholesterol in adults (adult treatment panel III) final report. Circulation 2002;106:3143-3421.

42. Alberti KG, Zimmet PZ. Definition, diagnosis and classification of diabetes mellitus and its complications. Part 1: diagnosis and classification of diabetes mellitus provisional report of a WHO consultation. Diabet Med 1998;15:539-553. 
43. Balkau B, Charles MA. Comment on the provisional report from the WHO consultation. European Group for the Study of Insulin Resistance (EGIR). Diabet Med 1999;16:442-443.

44. Alberti KG, Eckel RH, Grundy SM, et al. Harmonizing the metabolic syndrome: a joint interim statement of the International Diabetes Federation Task Force on Epidemiology and Prevention; National Heart, Lung, and Blood Institute; American Heart Association; World Heart Federation; International Atherosclerosis Society; and International Association for the Study of Obesity. Circulation 2009;120:1640-1645.

45. Codoner-Franch P, Tavarez-Alonso S, Murria-Estal R, et al. Nitric oxide production is increased in severely obese children and related to markers of oxidative stress and inflammation. Atherosclerosis 2011;215:475-480.

46. Boden G. Obesity, insulin resistance and free fatty acids. Curr Opin Endocrinol Diabetes Obes 2011;18:139-143.

47. Briet $M$, Schiffrin EL. The role of aldosterone in the metabolic syndrome. Curr Hypertens Rep 2011;13:163-172.

48. Alberici LC, Vercesi AE, Oliveira HC. Mitochondrial energy metabolism and redox responses to hypertriglyceridemia. J Bioenerg Biomembr 2011;43:19-23.

49. Datla SR, Griendling KK. Reactive oxygen species, NADPH oxidases, and hypertension. Hypertension 2010;56:325-330.

50. Lassegue B, Griendling KK. NADPH oxidases: functions and pathologies in the vasculature. Arterioscler Thromb Vasc Biol 2010;30:653-661.

51. Doughan AK, Harrison DG, Dikalov SI. Molecular mechanisms of angiotensin II-mediated mitochondrial dysfunction - linking mitochondrial oxidative damage and vascular endothelial dysfunction. Circ Res 2008;102:488-496.

52. Harrison DG, $\mathrm{Cai} \mathrm{H}$, Landmesser $\mathrm{U}$, et al. Interactions of angiotensin II with $\mathrm{MAD}(\mathrm{P}) \mathrm{H}$ oxidase, oxidant stress and cardiovascular disease. J Renin Angiotensin Aldosterone Syst 2003:4:51-61.

53. Harrison DG, Gongora MC. Oxidative stress and hypertension. Med Clin N Am 2009;93:621-635.

54. Landmesser $\mathrm{U}$, Dikalov $\mathrm{S}$, Price $\mathrm{SR}$, et al. Oxidation of tetrahydrobiopterin leads to uncoupling of endothelial cell nitric oxide synthase in hypertension. J Clin Invest 2003;111:1201-1209.

55. Warnholtz A, Nickenig G, Schulz E, et al. Increased NADH-oxidasemediated superoxide production in the early stages of atherosclerosis: evidence for involvement of the renin-angiotensin system. Circulation 1999;99:2027-2033.

56. Baldus $\mathrm{S}$, Mullerleile $\mathrm{K}$, Chumley $\mathrm{P}$, et al. Inhibition of xanthine oxidase improves myocardial contractility in patients with ischemic cardiomyopathy. Free Radic Biol Med 2006;41:1282-1288.

57. White $\mathrm{CR}$, Darley-Usmar V, Berrington WR, et al. Circulating plasma xanthine oxidase contributes to vascular dysfunction in hypercholesterolemic rabbits. Proc Natl Acad Sci USA 1996;93: 8745-8749.

58. Nicholls SJ, Hazen SL. Myeloperoxidase, modified lipoproteins, and atherogenesis. J Lipid Res 2009;50:S346-S351.

59. Podrez EA, Abu-Soud HM, HAzen SL. Myeloperoxidase-generated oxidants and atherosclerosis. Free Radic Biol Med 2000;28:1717-1725.

60. Wang Z, Nicholls SJ, Rodriguez ER, et al. Protein carbamylation links inflammation, smoking, uremia and atherogenesis. Nat Med 2007;13:1176-1184.

61. Ballinger SW, Patterson C, Knight-Lozano CA, et al. Mitochondrial integrity and function in atherogenesis. Circulation 2002;106:544549. Ref Type: Generic.

62. Chuang GC, Yang Z, Westbrook DG, et al. Pulmonary ozone exposure induces vascular dysfunction, mitochondrial damage, and atherogenesis. Am J Physiol Lung Cell Mol Physiol 2009;297: L209-L216.

63. Knight-Lozano CA, Young CG, Burow DL, et al. Cigarette smoke exposure and hypercholesterolemia increase mitochondrial damage in cardiovascular tissues. Circulation 2002;105:849-854.

64. Yang $Z$, Knight $C A$, Mamerow $M$, et al. Prenatal environmental tobacco smoke exposure promotes adult atherogenesis and mitochondrial damage in apoE-/- mice fed a chow diet. Circulation 2004;110:3715-3720

65. Rodriguez-Iturbe $B$, Sepassi $L$, Quiroz $Y$, et al. Association of mitochondrial SOD deficiency with salt-sensitive hypertension and accelerated renal senescence. J Appl Physiol 2007;102:255-260.
66. Chen C, Korshunov VA, Massett MP, et al. Impaired vasorelaxation in inbred mice is associated with alterations in both nitric oxide and super oxide pathways. J Vasc Res 2007;44:504-512.

67. Bernal-Mizrachi C, Gates AC, Weng $S$, et al. Vascular respiratory uncoupling increases blood pressure and atherosclerosis. Nature 2005;435:502-506.

68. Gates AC, Bernal-Mizrachi C, Chinault SL, et al. Respiratory uncoupling in skeletal muscle delays death and diminishes age-related disease. Cell Metab 2007;6:497-505.

69. Teshima $\mathrm{Y}$, Akao $\mathrm{M}$, Jones SP, et al. Uncoupling protein-2 overexpression inhibits mitochondrial death pathway in cardiomyocytes. Circ Res 2003;93:192-200.

70. Kim HS, Park KG, Koo TB, et al. The modulating effects of the overexpression of uncoupling protein 2 on the formation of reactive oxygen species in vascular cells. Diabetes Res Clin Pract 2007;77:S46-S48.

71. Lee $\mathrm{KU}$, Lee IK, Han J, et al. Effects of recombinant adenovirusmediated uncoupling protein 2 overexpression on endothelial function and apoptosis. Circ Res 2005;96:1200-1207.

72. Park JY, Park KG, Kim HJ, et al. The effects of the overexpression of recombinant uncoupling protein 2 on proliferation, migration and plasminogen activator inhibitor 1 expression in human vascular smooth muscle cells. Diabetologia 2005;48:1022-1028.

73. Blanc J, Alves-Guerra MC, Esposito B, et al. Protective role of uncoupling protein 2 in atherosclerosis. Circulation 2003;107: 388-390.

74. Willett WC. Balancing life-style and genomics research for disease prevention. Science 2002;296:695-698.

75. Stephens JW, Humphries SE. The molecular genetics of cardiovascular disease: clinical implications. J Intern Med 2003;253:120-127.

76. Sundquist K, Li XJ. Differences in maternal and paternal transmission of coronary heart disease. Am J Prev Med 2006;30:480-486.

77. Nilsson PM, Nilsson JA, Berglund G. Family burden of cardiovascular mortality: risk implications for offspring in a national register linkage study based upon the Malmo Preventive Project. J Intern Med 2004;255:229-235.

78. Schildkraut JM, Myers RH, Cupples A, et al. Coronary risk associated with age and sex of parental heart disease in the Framingham study. Am J Cardiol 1989;10:555-559.

79. Sesso HD, Lee IM, Gaziano JM, et al. Maternal and paternal history of myocardial infarction and risk of cardiovascular disease in men and women. Circulation 2001:104:393-398.

80. Ferrieres J, Lascaux-Lefebvre $\mathrm{V}$, Arveiler $\mathrm{D}$, et al. Influence of parental history of cardiovascular risk factors on multiple metabolic syndrome. Eur Heart J 2000;21:28.

81. Wada K, Tamakoshi K, Yatsuya $\mathrm{H}$, et al. Association between parental histories of hypertension, diabetes and dyslipidemia and the clustering of these disorders in offspring. Prev Med 2006:42:358-363.

82. Forouhi NG, Sattar N. CVD risk factors and ethnicity - a homogeneous relationship? Atheroscler Suppl 2006;7:11-19.

83. Sullivan J. Salt sensitivity: definition, conception, methodology, and long term issues. Hypertension 1991;17:161-168.

84. Luft F, Grim C, Fineberg N, et al. Effects of volume expansion and contraction in normotensive whites, blacks, and subjects of different ages. Am J Cardiol 1979;59:643-650.

85. Weinberger M, Miller J, Luft F, et al. Definitions and characteristics of sodium sensitivity and blood pressure resistance. Hypertension 1986;8:II127-II134.

86. Luft F, Miller J, Grim C. Salt sensitivity and resistance of blood pressure: age and race as factors in physiological responses. Hypertension 1991;17:1102-I108.

87. Luft F. Heterogenious response to changes in dietary salt intake: the salt sensitivity paradigm. Am J Clin Nutr 1997;65:612S-617S.

88. Falkner $B, K a t z S$, Canessa $M$, et al. The response to long term sodium loading in young blacks. Hypertension 1986;8:I165-I168.

89. American Heart Association. Relevance of genetics and genomics for prevention and treatment of cardiovascular disease: a scientific statement from the AHA council on epidemiology and prevention, the stroke council, and the functional genomics and translational biology interdisciplinary working group. Circulation 2007;115: 2878-2901.

90. Hirschhorn JN, Daly MJ. Genome-wide association studies for common diseases and complex traits. Nat Rev Genet 2005;6:95-108. 
91. van Schooten FJ, Hirvonen A, Maas LM, et al. Putative susceptibility markers of coronary artery disease: association between VDR genotype, smoking, and aromatic DNA adduct levels in human right atrial tissue. FASEB J 1998;12:1409-1417.

92. Connelly JJ, Wang T, Cox JE, et al. GATA2 is associated with familial early-onset coronary artery disease. PLoS Genet 2006;2:1265-1273.

93. Humphries SE, Talmud PJ, Hawe E, et al. Apolipoprotein E4 and coronary heart disease in middle-aged men who smoke: a prospective study. Lancet 2001;358:115-119.

94. Talmud PJ, Humphries SE. Gene: environment interaction in lipid metabolism and effect on coronary heart disease risk. Curr Opin Lipidol 2002;13:149-154.

95. Keavney B, Parish S, Palmer A, et al. Large-scale evidence that the cardiotoxicity of smoking is not significantly modified by the apolipoprotein $\mathrm{E}$ epsilon 2/epsilon 3/epsilon 4 genotype. Lancet 2003;361:396-398.

96. Wheeler JG, Keavney BD, Watkins $\mathrm{H}$, et al. Four paraoxonase gene polymorphisms in 11,212 cases of coronary heart disease and 12,786 controls: meta-analysis of 43 studies. Lancet 2004;363: 689-695.

97. Wang XS, Ria M, Kelmenson PM, et al. Positional identification of TNFSF4, encoding OX40 ligand, as a gene that influences atherosclerosis susceptibility. Nat Genet 2005;37:365-372.

98. Wallace DC. A mitochondrial paradigm for degenerative diseases and ageing. Novartis Found Symp 2001;235:247-263.

99. Wallace DC. The mitochondrial genome in human adaptive radiation and disease: on the road to therapeutics and performance enhancement. Gene 2005;354:169-180.

100. Wallace DC. A mitochondrial paradigm of metabolic and degenerative diseases, aging, and cancer: a dawn for evolutionary medicine. Annu Rev Genet 2005;39:359-407.

101. Ballinger SW. Mitochondrial dysfunction in cardiovascular disease. Free Radic Biol Med 2005;38:1278-1295.

102. Ballinger SW. Deregulation of mitochondrial function: a potential common theme for cardiovascular disease development. In: Miwa S Beckman KB, Muller FL (eds). Aging Medicine: Oxidative Stress in Aging: From Model Systems to Human Diseases. Humana Press: Totowa, NJ, 2008, pp 165-189.

103. Trounce I, Byrne E, Marzuki S. Decline in skeletal muscle mitochondrial respiratory chain function: possible factor in ageing. Lancet 1989;1:44-45.

104. Holt IJ, Harding $A E$, Morgan-Hughes JA. Deletions of muscle mitochondrial DNA in patients with mitochondrial myopathies. Nature 1988;331:717-719.

105. Schurr TG. The peopling of the New World: perspectives from molecular anthropology. Annu Rev Anthropol 2004;33:551-583.

106. Jorde LB, Watkins WS, Bamshad MJ, et al. The distribution of human genetic diversity: a comparison of mitochondrial, autosomal, and Ychromosome data. Am J Human Genet 2000;66:979-988.

107. Barker DJ. Fetal origins of coronary disease. BMJ 1995;311:171-174.

108. Hales CN, Barker DJ. The thrifty phenotype hypothesis. Brit Med Bull 2001;60:5-20.

109. Margulis L. Origin of mitochondria and hydrogenosomes. Hist Philos Life Sci 2008;30:473-477.

110. Gow A, Duran D, Thom S, et al. Carbon dioxide enhancement of peroxynitrite mediated protein tyrosine nitration. Arch Biochem Biophys 1996;333:42-48.

111. Milton K. Hunter-gatherer diets - a different perspective. Am J Clin Nutr 2000;71:665-667.

112. Cordain L, Brand-Miller J, Eaton SB, et al. Plant-animal subsistence ratios and macronutrient energy estimations in worldwide huntergatherer diets. Am J Clin Nutr 2000;71:682-692.

113. Ruiz-Pesini E, Mishmar D, Brandon M, et al. Effects of purifying and adaptive selection on regional variation in human mtDNA. Science 2004;303:223-226

114. Fahlman A, Storey JM, Storey KB. Gene up-regulation in heart during mammalian hibernation. Cryobiology 2000;40:332-342.

115. Muleme HM, Walpole AC, Staples JF. Mitochondrial metabolism in hibernation: metabolic suppression, temperature effects, and substrate preferences. Physiol Biochem Zool 2006;79:474-483.

116. Shug AL, Ferguson S, Shrago $E$, et al. Changes in respiratory control and cytochromes in liver mitochondria during hibernation. Biochim Biophys Acta 1971;226:309-312.
117. Ide T, Tsutsui $\mathrm{H}$, Hayashidani $\mathrm{S}$, et al. Mitochondrial DNA damage and dysfunction associated with oxidative stress in failing hearts after myocardial infarction. Circ Res 2001;88:529-535.

118. Scott GR, Egginton S, Richards JG, et al. Evolution of muscle phenotype for extreme high altitude flight in the bar-headed goose. Proc Biol Sci 2009;276:3645-3653.

119. Scott GR, Schulte PM, Egginton S, et al. Molecular evolution of cytochrome $C$ oxidase underlies high-altitude adaptation in the barheaded goose. Mol Biol Evol 2011;28:351-363.

120. da Fonseca RR, Johnson WE, O'Brien SJ, et al. The adaptive evolution of the mammalian mitochondrial genome. BMC Genomics 2008;9:119.

121. Chen K, Thomas SR, Albano A, et al. Mitochondrial function is required for hydrogen peroxide-induced growth factor receptor transactivation and downstream signaling. J Biol Chem 2004;279:35079-35086.

122. Li A, Ito $\mathrm{H}$, Rovira $\mathrm{I}$, et al. A role for reactive oxygen species in endothelial cell anoikis. Circ Res 1999;85:304-310.

123. Schulze-Osthoff $K$, Beyaert $R$, Vandervoorde $V$, et al. Depletion of the mitochondrial electron transport abrogates the cytotoxic and geneinductive effects of TNF. EMBO J 1993;12:3095-3104.

124. Schulze-Osthoff $\mathrm{K}$, Bakker AC, Vanhaesebroeck B, et al. Cytotoxic activity of tumor necrosis factor is mediated by early damage of mitochondrial functions. Evidence for the involvement of mitochondrial radical generation. J Biol Chem 1992;267:5317-5323.

125. Daiber A. Redox signaling (cross-talk) from and to mitochondria involves mitochondrial pores and reactive oxygen species. Biochim Biophys Acta 2010;1797:897-906.

126. Yin JX, Yang RF, Li SM, et al. Mitochondria-produced superoxide mediates angiotensin II-induced inhibition of neuronal potassium current. Am J Physiol Cell Physiol 2010;298:C857-C865.

127. Go YM, Park $H$, Koval $M$, et al. A key role for mitochondria in endothelial signaling by plasma cysteine/cystine redox potential. Free Radic Biol Med 2010;48:275-283.

128. Arciuch VGA, Alippe $\mathrm{Y}$, Carreras $M C$, et al. Mitochondrial kinases in cell signaling: facts and perspectives. Adv Drug Deliv Rev 2009;61:1234-1249.

129. Gao Q, Zhao XM, Ahmad M, et al. Mitochondrial-derived hydrogen peroxide inhibits relaxation of bovine coronary arterial smooth muscle to hypoxia through stimulation of ERK MAP kinase. Am J Physiol Heart Circ Physiol 2009;297:H2262-H2269.

130. Huang SM, Zhang AH, Ding GX, et al. Aldosterone-induced mesangial cell proliferation is mediated by EGF receptor transactivation. Am J Physiol Renal Physiol 2009;296:F1323-F1333.

131. Han ZS, Varadharaj S, Giedt RJ, et al. Mitochondria-derived reactive oxygen species mediate heme oxygenase-1 expression in sheared endothelial cells. J Pharmacol Exp Ther 2009;329:94-101.

132. Hasebe $Y$, Egawa $K$, Shibanuma $M$, et al. Induction of matrix metalloproteinase gene expression in an endothelial cell line by direct interaction with malignant cells. Cancer Sci 2007;98:58-67.

133. Jones DP. Disruption of mitochondrial redox circuitry in oxidative stress. Chem Biol Interact 2006;163:38-53.

134. Gutierrez J, Ballinger SW, Darley-Usmar VM, et al. Free radicals, mitochondria, and oxidized lipids - the emerging role in signal transduction in vascular cells. Circ Res 2006;99:924-932.

135. Desouki MM, Kulawiec M, Bansal S, et al. Cross talk between mitochondria and superoxide generating NADPH oxidase in breast and ovarian tumors. Cancer Biol Ther 2005;4:1367-1373.

136. Felty Q, Roy D. Mitochondrial signals to nucleus regulate estrogeninduced cell growth. Med Hypotheses 2005;64:133-141.

137. Roy D, Cai QY, Felty Q, et al. Estrogen-induced generation of reactive oxygen and nitrogen species, gene damage, and estrogen-dependent cancers. J Toxicol Env Health B Crit Rev 2007; 10:235-257.

138. Bienengraeber M, Ozcan C, Terzic A. Stable transfection of UCP1 confers resistance to hypoxia/reoxygenation in a heart-derived cell line. J Mol Cell Cardiol 2003;35:861-865.

139. Bernal-Mizrachi C, Gates AC, Weng S, et al. Vascular respiratory uncoupling increases blood pressure and atherosclerosis. Nature 2005:435:502-506.

140. Bernal-Mizrachi C, Weng S, Li B, et al. Respiratory uncoupling lowers blood pressure through a leptin-dependent mechanism in genetically obese mice. Arterioscler Thromb Vasc Biol 2002;22:961-968. 
141. Bernal-Mizrachi C, Weng S, Bloodsworth AC, et al. Inducible expression of uncoupling protein-1 in mouse aortic smooth muscle cells promotes hypertension and atherosclerosis. Arterioscler Thromb Vasc Biol 2003;23:A76.

142. Asimakis G, Lick S, Patterson W. Postischemic recovery of contractile function is impaired in SOD2 (+/-) but not SOD1 (+/-) mouse hearts. Circulation 2002;105:981-986.

143. Chen Z, Siu B, Ho Y-S, et al. Overexpression of MnSOD protects against myocardial ischemia/reperfusion injury in transgenic mice. $J$ Mol Cell Cardiol 1998;30:2281-2289.

144. Fisher CJ, Goswami PC. Mitochondria-targeted antioxidant enzyme activity regulates radioresistance in human pancreatic cancer cells. Cancer Biol Ther 2008;7:1271-1279.

145. Ohashi M, Runge MS, Faraci FM, et al. MnSOD deficiency increases endothelial dysfunction in ApoE-deficient mice. Arterioscler Thromb Vasc Biol 2006:26:2331-2336.

146. Hoehn KL, Salmon AB, Hohnen-Behrens $C$, et al. Insulin resistance is a cellular antioxidant defense mechanism. Proc Natl Acad Sci USA 2009;106:17787-17792.

147. Boudina $\mathrm{S}$, Sena $\mathrm{S}$, Theobald $\mathrm{H}$, et al. Mitochondrial energetics in the heart in obesity-related diabetes - direct evidence for increased uncoupled respiration and activation of uncoupling proteins. Diabetes 2007;56:2457-2466.

148. Twig G, Elorza A, Molina AJA, et al. Fission and selective fusion govern mitochondrial segregation and elimination by autophagy. EMBO J 2008;27:433-446.

149. Civitarese AE, MacLean PS, Carling $S$, et al. Regulation of skeletal muscle oxidative capacity and insulin signaling by the mitochondria! Rhomboid protease PARL. Cell Metab 2010;11:412-426.

150. Wiederkehr A, Wollheim CB. Minireview: implication of mitochondria in insulin secretion and action. Endocrinology 2006;147:2643-2649.

151. Mattiasson G, Sullivan PG. Comprehensive invited review - the emerging functions of UCP2 in health, disease, and therapeutics. Antioxid Redox Signal 2006;8:1-38.

152. Fisler JS, Warden $\mathrm{CH}$. Uncoupling proteins, dietary fat and the metabolic syndrome. Nutr Metab 2006;3:38.

153. Leloup C, Tourrel-Cuzin C, Magnan C, et al. Mitochondrial reactive oxygen species are obligatory signals for glucose-induced insulin secretion. Diabetes 2009;58:673-681.

154. Pi JB, Bai YS, Zhang $\mathrm{Q}$, et al. Reactive oxygen species as a signal in glucose-stimulated insulin secretion. Diabetes 2007;56: 1783-1791.

155. Dokken BB, Saengsirisuwan V, Kim JS, et al. Oxidative stress-induced insulin resistance in rat skeletal muscle: role of glycogen synthase kinase-3. Am J Physiol Endocrinol Metab 2008;294:E615-E621.

156. Loh K, Deng HY, Fukushima A, et al. Reactive oxygen species enhance insulin sensitivity. Cell Metab 2009;10:260-272.

157. Chang AM, Halter JB. Aging and insulin secretion. Am J Physio Endocrinol Metab 2003:284:E7-E12.

158. Moreno-Loshuertos $\mathrm{R}$, Acin-Perez $\mathrm{R}$, Fernandez-Silva $\mathrm{P}$, et al. Differences in reactive oxygen species production explain the phenotypes associated with common mouse mitochondrial DNA variants. Nat Genet 2006:38:1261-1268.

159. Marcuello A, Martinez-Redondo D, Dahmani $Y$, et al. Steady exercise removes $\mathrm{VO}(2 \mathrm{max})$ difference between mitochondrial genomic variants. Mitochondrion 2009;9:326-330.

160. Martinez-Redondo D, Marcuello A, Casajus JA, et al. Human mitochondrial haplogroup $\mathrm{H}$ : the highest $\mathrm{VO} 2 \mathrm{max}$ consumer-is it a paradox? Mitochondrion 2010;10:102-107.

161. Corral-Debrinski M, Shoffner JM, Lott MT, et al. Association of mitochondrial DNA damage with aging and coronary atherosclerotic heart disease. Mutat Res 1992;275:169-180.

162. Ballinger SW, Shoffner JM, Hedaya EV, et al. Maternally transmitted diabetes and deafness associated with a $10.4 \mathrm{~kb}$ mitochondrial DNA deletion. Nat Genet 1992;1:11-15.

163. Ballinger SW, Shoffner JM, Wallace DC. Mitochondrial myopathies genetic-aspects. Curr Top Bioenerg 1994;17:59-98.

164. Shoffner JM, Lott MT, Lezza AM, et al. Myoclonic epilepsy and raggedred fiber disease (MERRF) is associated with a mitochondrial DNA tRNA(Lys) mutation. Cell 1990;61:931-937.

165. Shoffner JM, Fernhoff PM, Krawiecki NS, et al. Subacute necrotizing encephalopathy: oxidative phosphorylation defects and the ATPase 6 point mutation. Neurology 1992;42:2168-2174.
166. Wallace $D C$, Zheng $X X$, Lott $M T$, et al. Familial mitochondria encephalomyopathy (MERRF): genetic, pathophysiological, and biochemical characterization of a mitochondrial DNA disease. Cell 1988;55:601-610

167. Wallace DC, Shoffner JM, Watts RL, et al. Mitochondrial oxidative phosphorylation defects in Parkinson's disease. Ann Neurol 1992;32:113-114.

168. Wallace DC, Singh G, Lott MT, et al. Mitochondrial DNA mutation associated with Leber's hereditary optic neuropathy. Science 1988:242:1427-1430.

169. Brown MD, Sun FZ, Wallace DC. Clustering of Caucasian Leber hereditary optic neuropathy patients containing the 11778 or 14484 mutations on an mtDNA lineage. Am J Hum Genet 1997;60:381-387.

170. Brown MD, Starikovskaya $E$, Derbeneva $O$, et al. The role of mtDNA background in disease expression: a new primary LHON mutation associated with Western Eurasian haplogroup J. Hum Genet 2002;110:130-138.

171. Brown MD, Zhadanov S, Allen JC, et al. Novel mtDNA mutations and oxidative phosphorylation dysfunction in Russian LHON families. Hum Genet 2001;109:33-39.

172. Brown MD, Derbeneva OA, Starikovskaya $Y$, et al. The influence of mtDNA background on the disease process: a new primary Leber's Hereditary Optic Neuropathy mtDNA mutation requires European haplogroup J for expression. Am J Hum Genet 2001;69:578.

173. Chagnon $\mathrm{P}$, Gee $\mathrm{M}$, Filion $\mathrm{M}$, et al. Phylogenetic analysis of the mitochondrial genome indicates significant differences between patients with Alzheimer disease and controls in a French-Canadian founder population. Am J Med Genet 1999;85:20-30.

174. De Benedictis G, Rose G, Carrieri G, et al. Mitochondrial DNA inherited variants are associated with successful aging and longevity in humans. FASEB J 1999:13:1532-1536.

175. Rose G, Passarino G, Carrieri G, et al. Paradoxes in longevity: sequence analysis of mtDNA haplogroup J in centenarians. Eur J Hum Genet 2001;9:701-707.

176. Goto $Y$, Nonaka I, Horai S. A mutation in the tRNA(Leu)(UUR) gene associated with the MELAS subgroup of mitochondrial encephalomyopathies. Nature 1990;348:651-653.

177. van den Ouweland JMW, Lemkes HHPJ, Ruitenbeek W. Mutation in mitochondrial tRNALeu(UUR) gene in a large pedigree with maternally transmitted type II diabetes mellitus and deafness. Nat Genet 1992;1:368-371.

178. van der Walt JM, Nicodemus KK, Martin ER, et al. Mitochondrial polymorphisms significantly reduce the risk of Parkinson disease. Am J Hum Genet 2003;72:804-811.

179. van der Walt JM, Dementieva YA, Martin ER, et al. Analysis of European mitochondrial haplogroups with Alzheimer disease risk. Neurosci Lett 2004;365:28-32.

180. Niemi AK, Hervonen A, Hurme $M$, et al. Mitochondrial DNA polymorphisms associated with longevity in a Finnish population. Hum Genet 2003;112:29-33.

181. McMahon FJ, Chen YS, Patel S, et al. Mitochondrial DNA sequence diversity in bipolar affective disorder. Am J Psychiatry 2000;157: 1058-1064.

182. Petros JA, Baumann AK, Ruiz-Pesini $E$, et al. mtDNA mutations increase tumorigenicity in prostate cancer. Proc Natl Acad Sci USA 2005;102:719-724.

183. Johnson KR, Zheng QY, Bykhovskaya Y, et al. A nuclear-mitochondrial DNA interaction affecting hearing impairment in mice. Nat Genet 2001:27:191-194.

184. Bhopal RS, Rafnsson SB. Could mitochondrial efficiency explain the susceptibility to adiposity, metabolic syndrome, diabetes and cardiovascular diseases in South Asian populations? Int J Epidemio 2009;38:1072-1081.

185. Amo T, Yadava N, Oh $\mathrm{R}$, et al. Experimental assessment of bioenergetic differences caused by the common European mitochondrial DNA haplogroups H and T. Gene 2008;411:69-76.

186. Amo T, Brand MD. Were inefficient mitochondrial haplogroups selected during migrations of modern humans? A test using modular kinetic analysis of coupling in mitochondria from cybrid cell lines. Biochem J 2007:404:345-351.

187. Gomez-Duran A, Pacheu-Grau D, Lopez-Gallardo E, et al. Unmasking the causes of multifactorial disorders: OXPHOS differences between mitochondrial haplogroups. Hum Mol Genet 2010;19:3343-3353. 
188. Roubertoux PL, Sluyter F, Carlier M, et al. Mitochondrial DNA modifies cognition in interaction with the nuclear genome and age in mice. Nat Genet 2003;35:65-69.

189. Gimsa U, Kanitz E, Otten W, et al. Behavior and stress reactivity in mouse strains with mitochondrial DNA variations. Ann NY Acad Sci 2009;1153:131-138.

190. Yu X, Gimsa U, Wester-Rosenlof $L$, et al. Dissecting the effects of mtDNA variations on complex traits using mouse conplastic strains. Genome Res 2009;19:159-165.

191. $\mathrm{Yu} \mathrm{XH}$, Wester-Rosenlof L, Gimsa U, et al. The mtDNA nt7778 $\mathrm{G} / \mathrm{T}$ polymorphism affects autoimmune diseases and reproductive performance in the mouse. Hum Mol Genet 2009;18: 4689-4698.

192. Schieke SM, Finkel T. Mitochondrial signaling, TOR, and life span. Biol Chem 2006;387:1357-1361.

193. Karu TI. Mitochondrial signaling in mammalian cells activated by red and near-IR radiation. Photochem Photobiol 2008;84: 1091-1099.

194. Ristow M, Zarse K. How increased oxidative stress promotes longevity and metabolic health: the concept of mitochondrial hormesis (mitohormesis). Exp Gerontol 2010;45:410-418.

195. Jahnke VE, Sabido O, Freyssenet D. Control of mitochondrial biogenesis, ROS level, and cytosolic Ca2+ concentration during the cell cycle and the onset of differentiation in L6E9 myoblasts. Am J Physiol Cell Physiol 2009;296:C1185-C1194.

196. Holley AK, Dhar SK, St Clair DK. Manganese superoxide dismutase vs. p53: regulation of mitochondrial ROS. Mitochondrion 2010 10:649-661.

197. Srinivasan S, Koenigstein A, Joseph J, et al. Role of mitochondrial reactive oxygen species in osteoclast differentiation. Ann NY Acad Sci 2010;1192:245-252.

198. Fridlyand LE, Philipson LH. Reactive species and early manifestation of insulin resistance in type 2 diabetes. Diabetes Obes Metab 2006;8:136-145.

199. Samocha-Bonet D, Heilbronn LK, Lichtenberg D, et al. Does skeletal muscle oxidative stress initiate insulin resistance in genetically predisposed individuals? Trends Endocrinol Metab 2010;21:83-88.

200. Mariappan N, Elks CM, Sriramula S, et al. NF-kappa B-induced oxidative stress contributes to mitochondrial and cardiac dysfunction in type II diabetes. Cardiovasc Res 2010;85:473-483.

201. Leduc L, Levy $E$, Bouity-Voubou $M$, et al. Fetal programming of atherosclerosis: possible role of the mitochondria. Eur J Obste Gynecol Reprod Biol 2010;149:127-130.

202. Kofler B, Mueller EE, Eder W, et al. Mitochondrial DNA haplogroup $T$ is associated with coronary artery disease and diabetic retinopathy: a case control study. BMC Med Genet 2009;10:35.

203. Gredilla R, Sanz A, Lopez-Torres M, et al. Caloric restriction decreases mitochondrial free radical generation at complex I and lowers oxidative damage to mitochondrial DNA in the rat heart. FASEB J 2001;15:1589-1591.

204. Lopez-Lluch G, Hunt N, Jones B, et al. Calorie restriction induces mitochondrial biogenesis and bioenergetic efficiency. Proc Natl Acad Sci USA 2006;103:1768-1773.

205. Gredilla R, Barja G. Minireview: the role of oxidative stress in relation to caloric restriction and longevity. Endocrinology 2005;146: 3713-3717.

206. Caro P, Gomez J, Lopez-Torres M, et al. Forty percent and eighty percent methionine restriction decrease mitochondrial ROS generation and oxidative stress in rat liver. Biogerontology 2008:9:183-196.

207. Caro P, Gomez J, Sanchez I, et al. Forty percent methionine restriction decreases mitochondrial oxygen radical production and leak at complex I during forward electron flow and lowers oxidative damage to proteins and mitochondrial DNA in rat kidney and brain mitochondria. Rejuvenation Res 2009;12:421-434.

208. Sanz A, Caro P, Ayala V, et al. Methionine restriction decreases mitochondrial oxygen radical generation and leak as well as oxidative damage to mitochondrial DNA and proteins. FASEB J 2006;20: 1064-1073.

209. Sanz A, Gomez J, Caro P, et al. Carbohydrate restriction does not change mitochondrial free radical generation and oxidative DNA damage. J Bioenerg Biomembr 2006;38:327-333.
210. Sanz A, Caro P, Sanchez JG, et al. Effect of lipid restriction on mitochondrial free radical production and oxidative DNA damage. Underst Modulat Aging 2006;1067:200-209.

211. Gomez J, Caro P, Sanchez I, et al. Effect of methionine dietary supplementation on mitochondrial oxygen radical generation and oxidative DNA damage in rat liver and heart. J Bioenerg Biomembr 2009;41:309-321.

212. Iso H, Rexrode KM, Stampfer MJ, et al. Intake of fish and omega-3 fatty acids and risk of stroke in women. JAMA 2001;285:304-312.

213. Simon JA, Hodgkins ML, Browner WS, et al. Serum fatty-acids and the risk of coronary heart-disease. Am J Epidemiol 1995;142:469-476.

214. Hu FB, Cho EY, Rexrode KM, et al. Fish and long-chain omega-3 fatty acid intake and risk of coronary heart disease and total mortality in diabetic women. Circulation 2003;107:1852-1857.

215. Hu FB. Plant-based foods and prevention of cardiovascular disease: an overview. Am J Clin Nutr 2003;78:544S-551S.

216. Hagopian K, Weber KL, Hwee DT, et al. Complex I-associated hydrogen peroxide production is decreased and electron transport chain enzyme activities are altered in $n-3$ enriched fat- 1 mice. PLoS One 2010;5:e12696.

217. Borra MT, Smith BC, Denu JM. Mechanism of human SIRT1 activation by resveratrol. J Biol Chem 2005;280:17187-17195.

218. Baur JA, Pearson KJ, Price NL, et al. Resveratrol improves health and survival of mice on a high-calorie diet. Nature 2006;444: 337-342.

219. Sulaiman M, Matta MJ, Sunderesan NR, et al. Resveratrol, an activator of SIRT1, upregulates sarcoplasmic calcium ATPase and improves cardiac function in diabetic cardiomyopathy. Am J Physiol Heart Circ Physiol 2010;298:H833-H843.

220. Maalouf M, Sullivan PG, Davis L, et al. Ketones inhibit mitochondrial production of reactive oxygen species production following glutamate excitotoxicity by increasing $\mathrm{NADH}$ oxidation. Neuroscience 2007;145:256-264.

221. Mattson MP, Chan SL, Duan WZ. Modification of brain aging and neurodegenerative disorders by genes, diet, and behavior. Physiol Rev 2002;82:637-672.

222. Neal EG, Chaffe $H$, Schwartz RH, et al. The ketogenic diet for the treatment of childhood epilepsy: a randomised controlled trial. Lancet Neurol 2008;7:500-506.

223. Gasior M, Rogawski MA, Hartman AL. Neuroprotective and diseasemodifying effects of the ketogenic diet. Behav Pharmacol 2006;17:431-439.

224. Ahola-Erkkila S, Carroll CJ, Peltola-Mjosund K, et al. Ketogenic diet slows down mitochondrial myopathy progression in mice. Hum Mol Genet 2010;19:1974-1984.

225. Dashti HM, Bo-Abbas YY, Asfar SK, et al. Ketogenic diet modifies the risk factors of heart disease in obese patients. Nutrition 2003;19:901-902.

226. Anderson EJ, Lustig ME, Boyle $\mathrm{KE}$, et al. Mitochondrial $\mathrm{H} 2 \mathrm{O} 2$ emission and cellular redox state link excess fat intake to insulin resistance in both rodents and humans. J Clin Invest 2009;119:573-581.

227. Williamson JR, Chang $\mathrm{K}$, Frangos $\mathrm{M}$, et al. Hyperglycemic pseudohypoxia and diabetic complications. Diabetes 1993;42: 801-813.

228. Gaikwad A, Long DJ, Stringer JL, et al. In vivo role of $\mathrm{NAD}(\mathrm{P}) \mathrm{H}$ : quinone oxidoreductase 1 (NQO1) in the regulation of intracellular redox state and accumulation of abdominal adipose tissues. J Biol Chem 2001;276:22559-22564.

229. Mongan PD, Capacchione J, West S, et al. Pyruvate improves redox status and decreases indicators of hepatic apoptosis during hemorrhagic shock in swine. Am J Physiol Heart Circ Physiol 2002;283:H1634-H1644.

230. MacDonald MJ, Marshall LK. Mouse lacking NAD(+)-linked glycero phosphate dehydrogenase has normal pancreatic beta cell function but abnormal metabolite pattern in skeletal muscle. Arch Biochem Biophys 2000;384:143-153.

231. Lin SJ, Guarente L. Nicotinamide adenine dinucleotide, a metabolic regulator of transcription, longevity and disease. Curr Opin Cell Biol 2003; $15: 241-246$

232. Easlon E, Tsang F, Skinner C, et al. The malate-aspartate NADH shuttle components are novel metabolic longevity regulators required for calorie restriction-mediated life span extension in yeast. Genes Dev 2008;22:931-944. 
233. Bobyleva V, Pazienza L, Muscatello U, et al. Short-term hypothermia activates hepatic mitochondrial sn-glycerol-3-phosphate dehydrogenase and thermogenic systems. Arch Biochem Biophys 2000;380:367-372.

234. Shen WY, Wei YD, Dauk $M$, et al. Involvement of a glycerol-3phosphate dehydrogenase in modulating the $\mathrm{NADH} / \mathrm{NAD}(+)$ ratio provides evidence of a mitochondrial glycerol-3-phosphate shuttle in Arabidopsis. Plant Cell 2006;18:422-441.

235. Raha S, Robinson BH. Mitochondria, oxygen free radicals, disease and ageing. Trends Biochem Sci 2000;25:502-508.

236. Malinska D, Kulawiak B, Kudin AP, et al. Complex III-dependent superoxide production of brain mitochondria contributes to seizurerelated ROS formation. Biochim Biophys Acta Bioenerg 2010;1797:1163-1170

237. Drose $S, B r a n d t ~ U$. The mechanism of mitochondrial superoxide production by the cytochrome bc(1) complex. J Biol Chem 2008;283:21649-21654.

238. Lambert A, Brand M. Superoxide production by NADH:ubiquinone oxidoreductase (complex I) depends on the $\mathrm{pH}$ gradient across the mitochondrial inner membrane. Biochem J 2004;382(Pt 2):511-517.

239. Cadenas E, Davies KJA. Mitochondrial free radical generation, oxidative stress, and aging. Free Radic Biol Med 2000;29:222-230.

240. Brand MD, Affourtit C, Esteves TC, et al. Mitochondrial superoxide: production, biological effects, and activation of uncoupling proteins. Free Radic Biol Med 2004;37:755-767.
241. Schonfeld P, Wojtczak L. Fatty acids decrease mitochondrial generation of reactive oxygen species at the reverse electron transport but increase it at the forward transport. Biochim Biophys Acta Bioenerg 2007;1767:1032-1040.

242. Murphy MP. How mitochondria produce reactive oxygen species. Biochem J 2009;417:1-13.

243. Jauslin ML, Meier $\mathrm{T}$, Smith RAJ, et al. Mitochondria-targeted antioxidants protect Friedreich Ataxia fibroblasts from endogenous oxidative stress more effectively than untargeted antioxidants. FASEB J 2003;17:1972-1974.

244. Caso G, Kelly P, McNurlan MA, et al. Effect of coenzyme Q10 on myopathic symptoms in patients treated with statins. Am J Cardiol 2007;99:1409-1412.

245. Khatta $M$, Alexander BS, Krichten CM, et al. The effect of coenzyme $\mathrm{Q}(10)$ in patients with congestive heart failure. Ann Intern Med 2000;132:636-640.

246. de Bustos F, Molina JA, Jimenez-Jimenez FJ, et al. Serum levels of coenzyme $\mathrm{Q}(10)$ in patients with Alzheimer's disease. J Neural Transm 2000;107:233-239.

247. Dhanasekaran $M$, Ren J. The emerging role of coenzyme Q-10 in aging, neurodegeneration, cardiovascular disease, cancer and diabetes mellitus. Curr Neurovasc Res 2005;2:447-459.

248. Rodriguez-Hernandez A, Cordero MD, Salviati L, et al. Coenzyme Q deficiency triggers mitochondria degradation by mitophagy. Autophagy 2009;5:19-32. 